\title{
Change-making in a (post)apartheid city: An auto-ethnographical essay
}

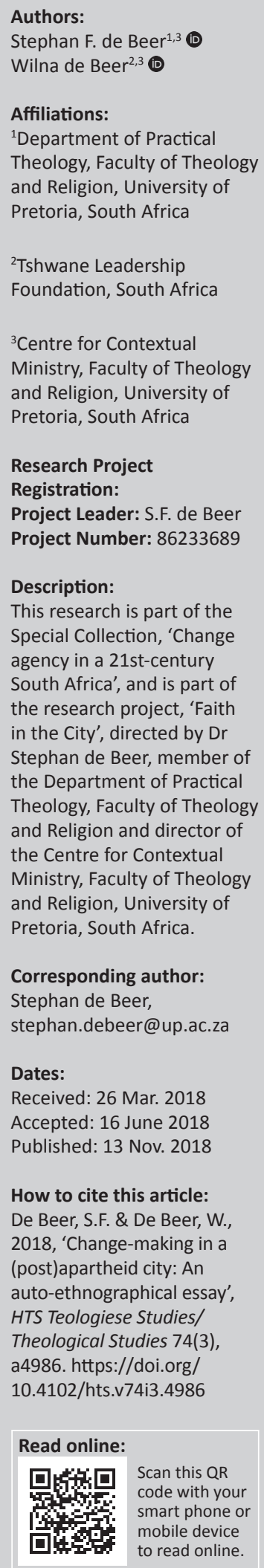

We reflect on living and doing ministry in a (post)apartheid South African city, negotiating ongoing demographic and sociopolitical transitions and discerning appropriate faith responses. We speak about the inevitability of these transitions, but then suggest that a view of theology and ministry as change-making is not inevitable but a vocation and art to be acknowledged, embraced and fostered. We argue for an epistemology from below or within, drawing from Parker Palmer's notion of knowing as loving - in community - and reflecting on his idea that 'to know' is 'to be known'. In stressing the importance of reading the city, we show how reading the city means to be read by the city too. It is in the journeys of ongoing self-awareness, and personal confrontation, change and conversion - in relation to issues of gender, race, location and class - that transformational urban imaginaries can be birthed. Finally, we reflect on urban change-making as a process of personal, communal, institutional and systemic transformation, happening on many different levels at the same time, through creating conditions and spaces for change to occur. It is an ongoing call for deepening our journeys in response to the overwhelming groans, of humanity and creation alike, for Gods' urban shalom.

\section{Introduction}

During the early 1990s, during the time of transition from apartheid to a new era, a small group of individuals collectively sought to embark on a journey of change. We longed to be part of a community that could embody the humanity of Jesus in dehumanised urban places; we were intentionally anti-racist and anti-sexist; and we were excited about participating in a small way in the re-authoring of inner city narratives, beyond 1994. That led to the birth of a community then known as Pretoria Community Ministries, today as the Tshwane Leadership Foundation (TLF). Six local inner city churches from six different denominations served as midwife to facilitate the birthing process.

In those early years, we did not necessarily have the language or consciousness to reflect on whiteness or blackness in the ways it is reflected upon now. We understood racial categories and the evil system of apartheid and were hell-bent to do what we could, in our small community, to shatter the edifices that damaged generations of people.

We realised soon enough that we could not embark on this journey void of a spirituality to undergird and sustain our journey. We were searching for companions or mentors to guide us, and such spiritual guides came in the form of a number of people spanning a wide range of Christian traditions. ${ }^{2}$ Less pronounced but always in the background was the work of Parker Palmer (1983a, 1983b, 1993, 1998, 2000, 2004). At some of our annual retreats, his words and thoughts resonated with our own journeys, and we started to consider him for our own reality. We will refer back to him later, exploring a spirituality of change-making. Besides those who helped to shape our spirituality, we had many other voices on this journey, helping us to make sense of both the urban challenge of the church ${ }^{3}$ and also the euphoria - and challenges - of the political transition that was underway in South Africa. ${ }^{4}$

1.Pretoria Community Ministries was formed in 1993 as an ecumenical community organization, with the support of six inner city
churches. In 2002, the name was changed to the TLF, both in alignment to the changing name of the metropolitan municipality in which
Pretoria resorts, but also as part of a global network of so-called Leadership Foundations.
2.Our collective spirituality was shaped by the work of people like Henri Nouwen (1972, 1979), Dorothee Soelle (1993, 2001), Jean Vanier
(1979), Elizabeth O'Connor (1976) and Letty Russell (1987) as well as others such as Gustavo Gutierrez (1988) and Donna Shaper (1989).
3.Urban theologians such as Aylward Shorter (1991), Ray Bakke (1987, 1997), Robert Linthicum (1991a, 1991b), Harvie Conn (1982) and
Roger Greenway (1979) deeply influenced our understanding of ministry in the city.
4.We were indebted to the likes of Albert Nolan (2001), Klippies Kritzinger (1991), Takatso Mofokeng (1983) and others, who helped
provide us with the theological frameworks necessary to deconstruct what we knew, as we sought to locate ourselves in fast-changing urban South African setting.

Copyright: @ 2018. The Authors. Licensee: AOSIS. This work is licensed under the Creative Commons Attribution License. 


\section{On change-making}

We will not dwell on different theories of change-making here, although we acknowledge their existence. ${ }^{5}$ Neither do we purport to offer a coherent theory of our own. This is, more likely, something of an auto-ethnographical essay, reflecting on being present in the inner city of Pretoria, the inner core of the City of Tshwane ${ }^{6}$ (referred to hereafter as Tshwane), for the past 25 years, as an expression of our desire to participate with many others in restorying the city. In doing so, we fuse personal or collective narrative with Parker Palmer's work on spirituality ${ }^{7}$; held together by a praxisapproach to urban engagement emanating from prophetic, liberationist traditions (cf. Cochrane, De Gruchy \& Petersen 1991; Holland \& Henriot 1992 [1983]) and charting what can perhaps be called a spirituality of change-making, or, even, city-making (cf. De Beer 2014). Therefore, instead of a theory of change, we perhaps veer in the direction of a spirituality of change-making, in a rather tentative way.

Our reflections in this article are in no way feigning neutrality. They are deeply shaped by intentional engagement with the idea or constructs of the (post)apartheid city. The (post) apartheid city had to deal with immense and in some cases dramatic and immediate change, causing disruption and crisis for some, and almost euphoric possibilities for creative engagement for others. And yet, we deliberately place (post) in brackets as the transformation process is ongoing. The city still invites ongoing and deliberate processes, postures and commitments in the direction of transformational change. ${ }^{8}$ These remain important so as to counter the legacy of colonial and apartheid segregation, exclusion and oppression.

We understand change-making as a vocation - or artful discipline - contributing towards the bigger project of societal transformation, through deliberate, disciplined and reflective interventions in what is regarded as inevitable. We draw deeply from our own rootedness in the prophetic tradition of liberation, but are further informed by the work of Ashoka: Innovators for the Public (Bornstein 2004:11), today a global network of social innovators committed to find solutions for some of society's greatest challenges.

\section{Change-making in the prophetic, liberationist tradition}

In considering change-making as city-making, we deliberately chose (and choose) and advocate for a position from

5.See a discussion or description for 'theories of change': Blamey and Mackenzie (2007), Connell and Kubisch (1998) and Fulbright-Anderson and Auspos (2006)

6.Pretoria, the administrative capital of South Africa, is now known as the City of Tshwane, which is the name of the metropolitan municipality. The old central core of the City of Tshwane, in which the inner city neighbourhoods resort, is still known as Pretoria. However, even for citizens of the city, this is all confusing. In this article, we will consistently refer to Tshwane.

7.Some of Parker Palmer's works that we consider here, include To Know As We Are Known: Education as a Spiritual Journey (1983a); The Company of Strangers: Christians and the Renewal of America's Public Life (1983b); The Promise of Paradox: A Celebration of Contradictions in the Christian Life (1993). The Courage to Teach: A Celebration of Contradictions in the Christian Life (1993); The Courage to Teach: Exploring the Inner Landscape of a Teachers' Life (1998); Let Your Life Speak Toward an Undivided Life (2004).

8.In this article, transformational change refers to personal, communal, institutional and systemic change in the sense of healing, restoration, redistribution and justice, mediated through sharing abundance aimed at integrated liberation or wholeness. below, as our epistemological point of departure. This is consistent with our own commitment to stand in the tradition of the Belhar Confession (1986): ${ }^{9}$

We believe that God has revealed Godself as the One who wishes to bring about true justice and true peace on earth; that in a world full of injustice and enmity God is in a special way the God of the destitute, the poor and the wronged and that God calls the church to follow God in this ... that the church as possession of God, should stand where God stands, namely against injustice and with the wronged. (p. 2)

From a position of solidarity, we seek to journey in such a way that we can participate with those who are wronged or excluded, ${ }^{10}$ discerning a socio-theological imagination for liberation-transformation to be mediated personally, communally, institutionally and systemically. We do so through an incarnational presence in local neighbourhoods, identifying Christ in the stranger and vulnerable, and deliberately fostering base communities (cf. Boff 1986:17; Gutierrez 1988:xli) with those who are extremely vulnerable, and therefore, with Christ.

The change we envision, and work for, draws from Gutierrez's (1988:xxxviii) understanding of salvation as liberation in a threefold sense: personal salvation or liberation from sin; liberation (freedom) from any obstacles denying human dignity or the possibility to experience fullness of life; but also socio-spatial-economic-political liberation. The base communities created by TLF are communities of discipleship, but also communities of care and humanisation, and, thirdly, communities advocating for justice. Moments and processes of liberation are aimed at mediating a sense of wholeness (healed fractures), both in a personal, spiritual or emotional sense, in interpersonal relationships, but also in the sense of socio-spatial-economic-political wholeness, which would include an insistence on managing the resources of God in the city well and justly.

Lastly, the journeys of TLF with vulnerable communities and people in the inner city of Tshwane, echoes something of a longing for liberation, globally expressed in manifold ways and beautifully described by Gutierrez (1988):

There is a longing for liberation that wells up from the inmost hearts of the poor and oppressed of this world and opens them up to receive the saving love of God. This longing is a sign of the active presence of the Spirit. (p. xvvviii)

Gutierrez (1988:xvvviii), instead of the narrow categories of salvation-liberation often peddled by missional movements or evangelical Christianity, speaks of integral liberation in response to the cry of the poor.

9.https://www.pcusa.org/site_media/media/uploads/theologyandworship/pdfs/ belhar.pdf

10.In our context, the most vulnerable include street homeless people; very vulnerable women or girl children; people living with chronic psycho-social illnesses without adequate social support systems; the LGBTIQ+ community; refugees or transnational migrants living in perpetual mothers who are homeless or trading informally on city pavenents, inner city residents living in precarious housing conditions, either informally or formally; or the frail elderly. There may very well be other equally or more vulnerable groups that we have not yet encountered. 


\section{Change-making as social innovation}

And yet, taking the cue from James Grant (quoted in Bornstein 2004:245), '[M]orality must march with capacity'. In our understanding of change-making, the best of the liberation tradition that names and deconstructs edifices of oppression and exclusion needs to be matched with the best of social innovation, that constructs radical alternatives in innovative and entrepreneurial ways, refusing to accept failure or the notion that 'there is no alternative' as the final word, demonstrating instead the viability of a socially just and equitable world. In this regard, our own conceptual understanding of change-making was deeply influenced by the work of Ashoka: Innovators for the Public, a global fellowship of social entrepreneurs, committed to changemaking through social innovation and entrepreneurship.

Ashoka (n.d.), on their website, describes their own selfunderstanding in this way:

Ashoka builds and cultivates a community of change leaders who see that the world now requires everyone to be a change-maker. Together, we collaborate to transform institutions and cultures worldwide so they support change-making for the good of society.

In the context of large-scale government failure to address some of society's greatest social and environmental challenges, 'it is the growing "citizen sector" that provides the necessary leadership, energy and innovation to correct these social problems' (Murthy, in Bornstein 2004:xii). Such leaders are described, in the language of Ashoka, as changemakers, social entrepreneurs or social innovators. What they hold in common is the ability to identify and articulate a specific societal challenge, to take ownership in finding innovative alternatives or solutions that will address the challenge and to work endlessly in their endeavour to scale the proven alternative or solution in order to benefit other communities in their own region or even globally.

Change-makers are people (or communities) who 'have powerful ideas to improve people's lives and they have implemented them across cities, and countries, and, in some cases, the world' (Bornstein 2004:1). Change-makers are 'relentless in the pursuit of their visions ... who simply will not take "no" for an answer, who will not give up until they have spread their ideas as far as they possibly can' (Bornstein 2004:1). They are about systemic and structural change, changing processes, policies, perceptions and paradigms (cf. Bornstein 2004:2). They combine 'entrepreneurial ability and strong ethical fiber' (Bornstein 2004:11).

In our approach, we combine faith language from the liberationist tradition (morality) with language of social innovation (capacity). Not all those who are Ashoka fellows necessarily do their work from a religious faith perspective. On the other hand, it seems clear that all of them share a conviction - and faith - in the possibility of a better, more humane, more just and more sustainable world. ${ }^{11}$

\section{Change-making as urban imaginaries of shalom}

Our own commitment to change-making is furthermore informed by urban theological imaginaries crafted and embodied by people like Father Ben Beltran in Smokey Mountain, Manila (cf. Beltran 2012); Reverend Hans Visser from the Paulus Kerk in Rotterdam (cf. Rowles \& Schell 2001) and Mary Nelson from Bethel New Life in Chicago (cf. Faith \& Leadership 2009); but also by urban faith communities such as the Abyssinian Development Corporation in Harlem, New York City; ${ }^{12}$ or the Centre for Transforming Mission in Kenya, working in some of the most challenging slum neighbourhoods of Nairobi. ${ }^{13}$ All of them hold in common a profound vision of God's shalom, which Robert Linthicum (1991a:86) describes as 'a state of wholeness and completeness possessed by a person or a group that includes good health, prosperity, security, justice, and deep spiritual contentment'. All of them are nurturing kingdom communities that display 'a whole new way of life on earth' (cf. Linthicum 1991a:89), expressed in lifestyle choices, but also the ways in which they are present in struggling urban communities to work for the liberation and transformation of people, places and all of creation.

Linthicum (1991a:90) says: 'Such a new style of life would have to include the transformation of the individual ... That style of life would also have to include the restructuring of all human society - economically, politically and religiously'.

\section{One example: A campaign to end street homelessness}

In our ownjourney with vulnerability and street homelessness in the inner city of Tshwane, it became apparent that deep change will only occur through a collaborative approach. The Tshwane Homelessness Forum was then launched as a platform in which homeless and former homeless people, non-profit and faith-based organisations, officials from the city and concerned residents can develop a more coordinated approach in addressing street homelessness.

After many years of endless and faithful commitment, with little signs of change, the past 4-5 years ushered in a new era of collaboration, and a sense of optimism that street homelessness in our city can be ended. Suddenly, the participation and agency of the homeless community itself, the adoption of a strategy by local government, the commitment of activist researchers from two local universities and the solidarity of civil society role players, all came together in a pledge to end street homelessness in our city. ${ }^{14}$ A range of innovative pilot projects were launched, the city is

who founded Common Ground and then Community Solutions in an effort to end homelessness in New York City and beyond and Patmanathen Pillai who started Life College to prepare students for life through liberating them 'from the apathy, low selfesteem, and ongoing psychosocial oppression that is apartheid's legacy' (Ashoka n.d.).

12.See www.adcorp.org

13.See www.ctmkenya.net

14.A description of this collaborative approach towards addressing homelessness in the City of Tshwane is found in 'Pathways out of homelessness. Research Report 2015', co-edited by De Beer and Vally (2015). 
actively seeking to make land or property available to house people, different organisations align their own missions to this resolve to end street homelessness and specific targets are being set to put the strategy into effect. Suburban 'champions' are emerging to organise resources and mobilise role players in 'new' areas of concentration for street homeless people, often close to employment opportunities.

Towards the end of 2017, a National Network on Street Homelessness was launched with representatives from five of South Africa's biggest cities participating. Already, the initiative to address street homelessness decisively is being scaled, and a next objective will be to influence the creation of a national policy and strategy on street homelessness. As a result of this dedicated and collaborative action in the same direction, over a long period of time, and the way in which it is developing into a national agenda, Tshwane has been elected as one of 10 pilot cities for a global campaign to end homelessness, launched by the Institute of Global Homelessness at the DePaul University in Chicago. ${ }^{15}$ At least two Ashoka fellows were instrumental in this process and what started off as different local initiatives around the globe are now becoming an interconnected global drive.

\section{The inevitability of change? Change- making as intentional irruption}

We make a distinction between change, whether for the good or the bad, and change-making as we frame it within a prophetic, liberationist tradition.

We reflect on living and ministry in a (post)apartheid South African city, in which we had to navigate firstly the dramatic wave of sociocultural change experienced in the inner city of Pretoria, and secondly the ongoing demographic and sociopolitical transitions experienced in the city. We had to discern faith responses at every new point of transition or whenever new challenges surfaced.

At some level, change is inevitable. Many changes post-1994 were good news for those previously excluded from the city. However, there is also the kind of change that is hurtful to the least of these, deliberately designed to (still) exclude them. Such change should never be regarded as inevitable but needs to be boldly resisted.

Examples of such exclusionary change often had to do with issues of land and property. One example, hurting an entire community in the inner city of Tshwane, was the forced relocation of 2000 people from an area called Marabastad in 2002. Marabastad is a place of rich history where different races lived and thrived together until the 1960s, before the full force of apartheid legislation de-Africanised this neighbourhood, and forced people from Marabastad, between 1965 and 1972, into different segregated townships around Pretoria. After the fall of apartheid people started to live informally in Marabastad, trying to create a better life for themselves and their families, through securing access to the opportunities and resources the city had to offer. The irony of the forced relocation of people in 2002 is devastating: the community of Marabastad - still not healed from the forced removals of 30 years ago - this time forcibly removed by the governing party of the liberation; at a time which was supposed to be filled with hope and new possibilities.

When we view theology and ministry as change-making, we consider it a chosen vocation and an artful discipline, to be accepted, embraced and fostered. We regard change-making as an intentional interruption of the status quo where the status quo denies some people their human and God-given dignity. Boesak (2017:81-85) writes about it as ' [i] interrupting the globalization of indifference'. One area of our faith engagement where the art of change-making is at its most sensitive and beautiful is in the moments of befriending people living on the urban streets, performed by different outreach teams. It is in the most inhumane and unkind spaces where 'the globalisation of indifference' is interrupted: when a young girl child stripped of her dignity, a ragged homeless person without food or a person using substances and selling sex to sustain the habit, is met with the opposite of the indifference, shame or rejection they experience daily - instead being embraced with love, kindness and unconditional acceptance.

We see change-making as multiple, unfolding irruptions from below, responding to apathy, oppression or life-denying change, until change in the direction of justice and wholeness will become the new inevitability. Instead of a rather individualised understanding of change-making, which is in a sense what Ashoka rewards through their fellowship programme, our understanding of change-making is more communal or collective, discerning where the Spirit is at work in history, the city or our own spaces, and then seeking to accompany, support and strengthen that which is unfolding.

An example is that of student movements emerging across the world, often in response to government failure. A specific expression thereof was found in the recent Fallist movement in South Africa. Boesak (2017), in reference to the Fallist movement, speaks about their irruption as 'an astonishingly hopeful voice'. He describes it as such, because he interprets this movement as follows:

Theirs is a commanding voice, inescapable because it is a voice not coming from strangers but from our own children. It is not at all just a voice of anger and reproach; it is an invitation to remember and reclaim the heritage of the prophetic tradition, the legacy we, they are still saying, even now despite our years of quietism, have left for them. (p. 196)

Boesak (2017:197) then refers to an inscription on her Facebook page by his daughter, Sarah Boesak (sent to him via email on 06 November 2015), after the students' marched on Parliament in Cape Town and the Union Buildings in Pretoria, in which she writes:

South Africans from every university, from every race, from every gender, from every province and from every economic 
grouping ... say in one collective voice that this oppression (which South Africans have been fighting for far too long) ends with us.

Sarah's words give an apt description of what we understand change-making to be: an intentional irruption into the status quo, naming the challenge (whether exclusion, oppression, abuse or violation) and boldly declaring that it will end with us. Change-making is an act, or a series of acts, of taking ownership for overcoming a specific societal challenge. Murthy (in Bornstein 2004:xii), with reference to social entrepreneurs or change-makers, says that the word 'entrepreneur' comes from a French word which means 'one who takes into hand'. Change-making is about taking into hand challenges that are at hand, refusing to accept the inevitability of such challenges and working endlessly to mediate transformation.

\section{A praxis-approach: Rooted in a lived faith; geared towards courageous action}

We have embraced a praxis-approach as methodology (cf. footnote 4) for our faith-based engagement with the city. The praxis-approach, in essence, is about change-making. It, namely, discerns actions of faith, appropriate in their response to locally experienced fractures, suffering, exclusion or pain. Figure 1 captures our understanding of the praxis-approach. It consists of the five distinct moments of insertion or immersion or entering, analysis or reading, theological reflection or imagination and planning for action or coconstruction (cf. De Beer 2017:16-23). At the heart of the cycle, informing and saturating every moment, and distinguishing it from methods used in sociology or other disciplines, is the notion of spirituality or 'lived faith' communally discerned and practised.

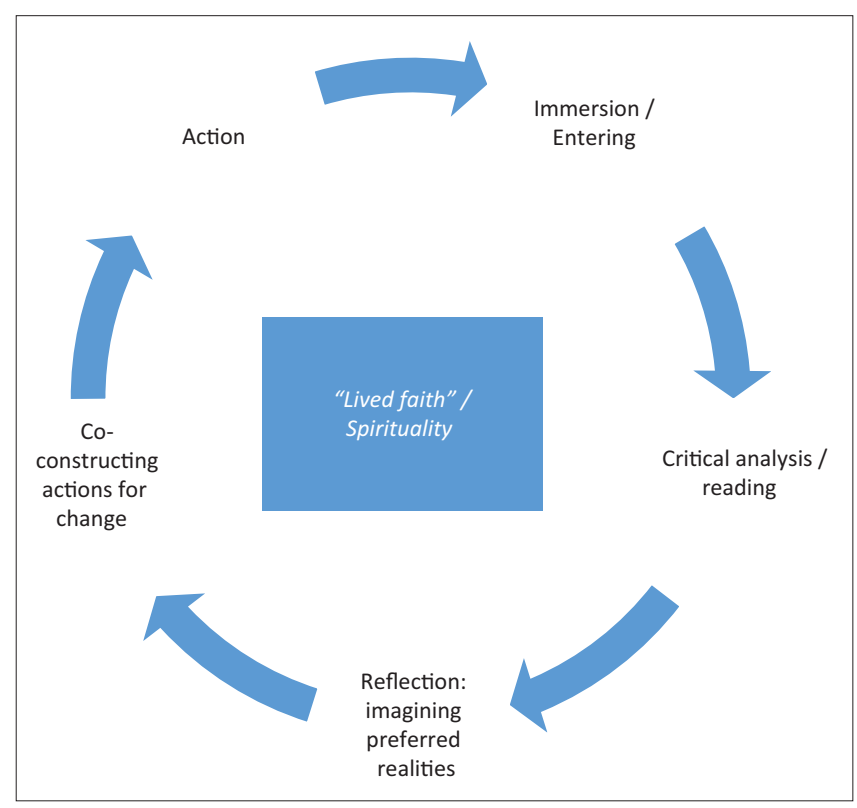

Source: Adapted from, De Beer, S. \& Venter, D., 1998, Doing theology in the city, Workbook One, Institute for Urban Ministry, Pretoria

FIGURE 1: The Praxis-Cycle.
Boff (1986:9) says every authentic theology originates in a spirituality: a strong encounter with God in history. The theology unfolding for TLF originated in a spirituality that had its origins in an encounter with an inner city God deeply concerned with injustices against some of the city's most vulnerable people (cf. Boff 1986:9).

In its most 'purist' form, the praxis-approach does not only depart from the assumption of a 'lived faith' but also has as prerequisite, or at least advocates for, embedded or incarnational action: this means that practitioners, urban ministers and even researchers are challenged not only to engage and disengage local communities as it suits them, but also to become fully part of the life of local communities. Often, this might require relocation of urban practitioners, physically moving into the places they choose to be in solidarity with. Such relocation, although it might mean placing oneself deliberately in a position of solidarity, also mostly means a displacement of sorts, either from neighbourhoods one knew or were a part of before, but it could also mean a displacement in terms of race, class, consciousness and positionality in society.

The community of TLF has chosen to insert themselves deeply into the context in which they long to do change-making. The issues facing the inner city of Pretoria became the issues facing each staff member on a personal level too - which church to be part of, which school to send children to, the conditions of the parks, transport, health clinics, the pavements and roads, all become matters of concern which affect their lives personally. The insertion of TLF in the inner city often means displacement of its staff - some, in terms of class, because the inner city is not seen as the 'right address' or places people in a different economic category; some, in terms of race, as the inner city with its predominantly black population invites white staff members to deal very intentionally with issues of whiteness and blackness; and others, in terms of identity, as working with the most vulnerable and marginalised of society, standing with God and them, sometimes led to the actual experiences of marginalisation of some team members from mainstream society. It is in this context that God uses those who were displaced and puts them into a new community - a community where mutual vulnerability is acknowledged and deep change-making made possible, a place where solidarity becomes real.

Grounded in lived faith, in local contexts and with local communities and people, a praxis-approach does not allow for critical analysis of local conditions to lead to some form of paralysis. Critical analysis includes a reading of the local context - both assets and needs - but also of structural and historical forces that shaped the local context. In addition, it reads the socio-ecclesial context, trying to understand how faith communities and other institutions engage local contexts. Such critical reading can be overwhelming as it oftentimes uncovers layers of abuse and abandonment, putting on stark display the ways in which some communities are used and extracted from, in the interest of building the wealth and futures of other communities. 
Instead of allowing for overwhelming experiences of bad power or death-dealing institutionalism to be paralysing, a praxis-approach draws from resources of faith to foster an alternative imagination or consciousness for preferred realities. Only when communities gain honest and deep insight into the workings of local communities and power in the city that they can begin to imagine the contrary. It is in reading local contexts in conjunction with Biblical texts where communities, places and people were abused or abandoned, or bad power exercised, that thematic sociotheological sources can be identified in order to inform or sustain alternative visions.

Once incarnational communities, living their faith deeply and critically, in solidarity with local communities, start to imagine what could be, courageous action almost becomes inevitable. Communities would start to discern the concrete actions to translate a different imagination into practice, considering the presence, postures, processes, programmes and policies that are required to ensure transformational change. In addition, it is in these courageous actions, together, sometimes small and tentative, sometimes bold and dramatic, that the seeds of change are hidden.

Two of the neighbourhoods in the inner city of Tshwane are Burgers Park and the tiny neighbourhood of Berea. They came together in what was known as the Berea Community Forum, a civic formation organising local neighbourhood concerns. Now dormant, this Forum did not imagine that they - at best a rather rag-tag and ad hoc group of people would have the power to close down illegal taverns, to confront banks about red-lining of inner city properties and to resist the sequestration of 18 inner city buildings at the hand of collusion between a prominent private property company and a local politician. And yet, through a combination of being immersed and vested in the community, making a sound and critical analysis, imagining the kind of community it wanted and taking collective and sustained action - it managed to build power from below, for the good of all.

To understand the praxis-approach well is to understand the criticality of each of the cycle's moments in conjunction with each other, the importance of practising the cycle in community and the choice to make the cycle an essential part of the discipline or rhythms of a local community's discernment processes.

The first insistence is to acknowledge each moment of the cycle as a discipline in itself: to be present in a deeply immersed way and to attend to the voices and desires of a local community (insertion or immersion), to read or deconstruct the layers that constitute local communities, to read the context well and continuously (analysis); to bring the readings of the context in conversation with biblical and other texts, fostering an alternative imagination (theological reflection); and to translate this imagination into concrete actions for change (planning for action). Each moment is important in itself, but also important in the ways in which it informs the other moments.
A second insistence is on doing the cycle in community. It is in our collective experiences of immersion, and in our diverse readings of context, that we help each other to develop an honest assessment of what is happening and why it is happening. The moment of theological reflection or theological imagining, again, should be a communal discipline if we are to develop an alternative consciousness together, which will be collectively owned. Moreover, deep change would remain elusive when translating such an imagination into concrete action without broad-based movements starting to give expression to a new vision of society.

A third insistence is on the praxis-cycle being embraced as part of the communal disciplines of a community's life together: it provides the structure and impetus to being intentional about its living together, its reading of the signs of the times, its reflective nurturing of new and subversive visions and its sustained actions - both resisting and reconstructing - in the direction of God's shalom.

\section{Change-making: Moments of discernment; postures of engagements; faces of leadership}

Based on our understanding of the praxis-approach, we have started to recognise the importance of this approach; not only as a contextual theological method for discerning our lives and vocation together, but also that the moments of the cycle could, perhaps, be considered as different postures of engagement and different faces of leadership.

The moment of insertion or immersion is really about creating a not-knowing, not-judging presence among people, being in deep solidarity and listening sensitively and carefully. It takes the posture of listening extremely seriously. The moment of analysis or critical reading is the posture of reading the signs of the times. It is a critical and deconstructive process, asking the 'why'-question, once one established some of the 'what' playing itself out in local communities. The 'why'question tends to be a dangerous, inconvenient question, because often, when starting to grapple with the reasons or causes of what we see and experience, we discover structural injustices, bad power and even our own complicity in creating and sustaining a certain status quo. The 'why'question should therefore be carefully asked, as the answers or clues might come at a considerable cost.

The moment of theological reflection is an imaginative moment in which we recognise the creativity of the Spirit who enables young people to see dreams and old people to see visions. It is a posture in which a community collectively dares to go beyond naming what is wrong, and beyond even suggesting that there can indeed be an alternative, to a place of boldly imagining and articulating those alternatives for all to hear and see. The fourth moment is indeed a moment of action, where daring imaginations are now embodied through courageous actions.

At the core of the cycle is an affirmation of the Spirit hovering over the city, longing to remember all that have been broken, 
and a 'lived faith' seeking to discern where the Spirit is at work, and to join in faithfully with that work. It departs from an understanding of God being at work in history, not abstractly but through concrete irruptions in the status quo. Or, as Gutierrez (1988) concludes:

the liberation actions of Christ - made human in this history and not in a history marginal to human life - is at the heart of the historical current of humanity; the struggle for a just society is in its own right very much part of salvation history. (p. 97)

The Spirit hovering over the city, and our attempts to be aligned to the promptings of this Spirit, is in response to the longings for liberation - whispered, groaned or shouted from the underside of the city.

Our sense is that these postures of a listening presence, reading the signs of the times, a daring imagination and courageous action, all springing from an affirmation of - and openness to - the Spirit hovering over the city, can then be translated into different faces of leadership, but the kind of leadership that is deliberate about change-making, and citymaking, which will honour the most vulnerable among us whilst preserving the integrity of creation.

We will not delve deeper into these faces of leadership here, but simply suggest that a praxis-approach consistently implemented and embraced as part of one's (spiritual) journey of engaging the city and other places, and will nurture leaders with these qualities and postures as part of their own make-up. In our understanding of change-making, five distinct faces of leadership need to be unlocked and nurtured for effective change to happen. We need simultaneously incarnational, analytical, reflective or imaginative, strategic and spiritual leadership.

Incarnational leaders choose to go deep down instead of graduating up and out. They serve among people and find their authority in letting go of dominant notions of power. Analytical leaders hone the tools and competencies to read their contexts and own institutions well, to understand the forces behind what the eyes can see and to deconstruct that which is oppressive and death-dealing, whilst naming and celebrating that which is life-affirming. Reflective leaders can be deeply rooted in action and engagement, but in ways that are reflective and making regular space for retreat and assessment. Reflective leaders, because of their closeness to reality, their criticality and their openness to the Spirit, also find it possible to help communities outline new imaginations. Strategic leaders refuse to be victims, or to stay stuck in analysis, or forever imagining change with no action to back it up. They translate dreams into sustainable actions and create networks and resources to carry and hold the dream, for as long as is needed for it to be birthed properly. In a society where soulfulness is squeezed from corporate boardrooms to the classrooms of higher education institutions, to even the approaches of managerialism of some new generation churches, spiritual leadership is disruptive in its insistence on communal discernment of the sacred amidst secularised urban spaces.

\section{Change towards what? On the content and spheres of transformational change}

As stated earlier, we consider change-making as 'on-going and deliberate processes, postures and commitments in the direction of transformational change, away from the legacy of colonial and apartheid segregation, exclusion and oppression'.

Theology as change-making is not "ethical philosophizing" that does nothing to transform the world' (Boesak 2017:198; in reference to Dutch theologian Abraham Kuyper in his Six Stones Lectures). Change-making is always deliberate and disciplined, geared towards and embodied by concrete transformative actions. It does not happen automatically.

Freire (1992:88) laments his own mistake of thinking that 'knowledge of reality and transformation of reality' were the same movement. The transformation of reality, Freire (1992:88) discovered, does not occur automatically because of 'the unveiling of reality'. Neither does it consist of the acquisition of existing knowledge. Change occurs in 'the creation of new knowledge' (Freire 1992:88) and through deliberate actions that will effect such change.

Such deep-seated transformational change has to be preceded by liberation. The content of black, liberation and feminist theologies is consistently that of liberation (cf. Boesak 1977:16-26).

Jesus purposely places himself in the prophetic tradition of preaching the liberation message ... This is especially clear in his first sermon in the synagogue of Nazareth, an event described in Luke 4. This text lies at the heart of the theology of liberation. (p. 20)

Liberation and humanisation go hand in hand. Paulo Freire (1992) speaks about mutuality in the process of being (de) humanised:

The oppressor is dehumanized in dehumanizing the oppressed. No matter that the oppressor eat well, be well regarded, or sleep well. It would be impossible to dehumanize without being dehumanized ... I am not, I do not be unless you are, unless you be. Above all, I am not if I forbid you to be. (p. 85)

Without the liberation that mediates humanisation, transformation will remain elusive. Freire (1992:84) speaks about 'the dream of humanization, whose concretization is always a process and always a becoming'. The same could be said of liberation and transformation, however. We are on journeys of becoming free and humanised, slowly transformed or restored into that which we are supposed to be, or which we have lost since birth (2 Cor 3:18). We located transformational change (liberation - humanisation transformation) in relation to various spheres - personal, communal, institutional and systemic; like concentric circles always spiralling further out. The content of such change includes healing and restoration; redistribution and justice. It gets mediated through sharing abundance aimed at integral liberation (cf. Gutierrez 1988:xxxviii), ${ }^{16}$ or wholeness.

16. of Gutierrez (1988:xxxviii) distinguishes between 'three levels or dimensions of liberation in Christ': liberation from sin and reconciliation with God; personal liberation in Christ': liberation from sin and reconciliation with God; personal
liberation distinguished by 'inner freedom', also to be seen as humanisation; and socioeconomic liberation from oppressive societal structures. 
In our journey, we have discovered the importance of language as a tool of oppression or of liberation. Oftentimes people surprised at our insistence on inclusive language, language that breaks down hierarchies and language that encourages agency, challenged us. We make sure not to use language that labels people in terms of race, gender, class or other categories, thereby encouraging and instilling solidarity and inclusivity. In the Tshwane Homelessness Forum, we always have to be attentive to some, who are not homeless, referring to those among us who experience homelessness as 'them', whilst those experiencing homelessness are in our midst as coleaders and full participants shaping the actions and thinking of the Forum in equal ways. We do not use terms such as 'help' and 'rehabilitate', as it relegates the other to a lesser position, suggesting their inability to help themselves; or, that we have some expert knowledge about their lives that they do not have themselves. It deprives the other of the possibility to practice their own agency, if their dignity was affirmed and agency invited through language that strengthens.

The change-making we refer to always aims at integral liberation-transformation. As Freire (1992:85) asserts: 'The liberation of individuals acquires profound meaning only when the transformation of society is achieved'. There is an interconnectedness between the liberation-transformation of individuals and society. We imagine both as preferred realities and work towards that.

\section{On a spirituality of change-making: Moments in the work of Parker Palmer}

In the next part, we will seek to fuse the praxis-approach with key elements from the work of Parker Palmer. We offer it as possible signposts, or a brief and rough outline, for a spirituality of change-making, at least in how it unfolded for us. Based in a faith community, we understand the entire cyclical process of the praxis-cycle as a process infused by the Spirit, a process of deep, ongoing and communal discernment; indeed, a spirituality of the circle.

At the precipice of change, different things can happen. One can either retreat into the known territory of one's own past. One can open one's arms into an unknown future and step in, adventurously. One can also wait on the precipice, neither stepping back nor stepping forward, either plunging oneself into an existential crisis or falling into a resolution almost accidentally, not of one's own making. For us, it was probably a combination of falling into a resolution whilst opening our arms to receive, or enter into, an unknown future.

\section{Deep immersion: 'To know as we are known'}

Immersing oneself in the complexities of local urban communities soon makes one realise that one is immersed '[I]n the belly of a paradox' (Palmer 1993:15-44): between diverse worlds of vast difference, competing values and conflicting meanings; between contesting visions and contesting spaces; between the church and the streets; between institution and movement; continuously trying to navigate unchartered waters, to know and to make sense.

Soon, we realised that the complexities and contradictions are such that anything but a 'not-knowing' approach would be self-defeating. At the same time, we obviously had a desire to know, in order to respond appropriately to some of the challenges the city faced. In this regard, Palmer's insistence on clarifying the 'origins and ends of knowledge' - the source and goal of our desire to know - became crucial.

Palmer (1983a:6-9) suggests that knowing fed by curiosity is often only about selfish interest, and knowledge becomes an end in itself. Knowing fed by control is the desire to know in order to have power over the other. Palmer (1983a:8) speaks about 'another kind of knowledge (that) is available to us, one that begins in a different passion and is drawn toward other ends'. This kind of knowing, Palmer (1983a:8) suggests, 'originate not in curiosity or control but in compassion or love'. Such a knowledge, he says, originating in love, has an entirely different goal, which is the reunification and reconstruction of broken selves and worlds' (Palmer 1983a:8).

As we immersed ourselves, not only did we face broken women in need of care and support, but we also faced our own broken selves and world. As we knew, together, we were known. As we faced racism, our own racial identities, our blackness and whiteness, were not unscathed. Journeys of knowing 'the other' became inward journeys of wrestling with self. We faced more questions, contradictions and challenges than we had clarity or answers. The depth of immersion surfaced critical questions, observations that we wanted to further engage through critical and ongoing readings of the context.

The TLF intentionally chose a posture of being a learning community, eager to learn from others on the journey and exposing itself to different models of praxis. It had to find its way through immersion and navigating between the margins and the mainstream. Freedman and Combs (2001:193) speak about knowledge as an activity or process that we do. Books, policies and procedures only have meaning when people use them, whilst knowledge is performed. It therefore always made sense in TLF to say that rules are made for people and not the other way round. Also, we learnt that as much as one can learn about advocacy in books and looking at best practice models, it would only be in the doing that we will learn how to navigate our own waters.

\section{Critical readings: 'Knowing in community'}

Communities of change-making are communities that develop the skill and discipline of engaging in critical readings of the community: the social composition, the institutional landscape, structural or systemic forces and the ecclesial responses. Such critical readings of a community 
cannot be performed well, or responsibly, if not performed in community, with many others. Different inhabitants of the city and different societal sectors hold different visions or perspectives on the city. They represent the multi-layered meaning derived from or assigned to the city.

Often, our knowing is obstructed by fear. Palmer (1998:50) describes such fearful ways of knowing, distinguishing between knowing that springs from fear, or that feeds or sustains fear, and knowing as loving, which is devoid of fear. Such knowing, he would argue, occurs primarily in community. Knowing in community stands in direct contrast to the privatisation of teaching (1998:142): instead of resorting to 'experts' who speak authoritatively into our life together, reflective communities are intentional about sharing (and) learning together, and assertive about what they know in community.

Doing theology from below cannot be done in isolation, or individually. The TLF community believes in consensusdriven processes, which always start with reflection and analysis, deep conversations and an opening up of space for dissenting voices. Such theology can only be practised in community (cf. Boff 1986:29), organically connected with the global church but also with global longings for freedom, expressed in social movements and radical faith communities irrupting from below.

The teaching style of TLF has grown into one of peer learning, in circles, instead of a 'banking style' of knowledge transfer (cf. Freire 1970), marked by the depositing of knowledge by 'experts' into 'containers', which are the passive students. Such a form of teaching or education negates the prior knowledge of participants or students, and does not make space for the critical interaction of such knowledge with the knowledge offered by the 'expert'. We resist the kind of teaching that is expert-driven as inappropriate in a context where so much is contested, where different knowledges compete for power, and where the beauty of knowing in community is such an opportunity. When the community grapples with an issue, only essential information is shared as a framework from which conversations flow and people's lived experience are shared. The deepest learning is extracted from rich conversations, through deconstructing unhelpful hierarchy, allowing all community members to feel valued, and with something to contribute.

The kind of discernment implied here is facilitated by the Spirit. In collective reading of the situation, in confronting of own fears, in seeking to overcome isolation in community, in learning to know together, the Spirit enables us to interpret the claims of the gospel, as they respond to the signs of the times (cf. Boff 1986:28).

\section{Reflective imagination: 'Whose life am I living?' and 'hidden wholeness'}

Once a community learns to know - and love - together, reading their community as discerning the sacred within, the next moment in the praxis-cycle becomes a moment of reflective imagination (or theological reflection). Often, prompted by our deep immersion and critical readings of a community, and being known as we are known, this is also a moment in which we start to ask: 'whose life am I living?' At a personal, and even a communal or institutional level, at this point, we are confronted (often afresh) with a question of identity, authenticity and integrity: Am I indeed living my own life and vocation? Am I true to myself, the community and God's dream for my life? Are my life actions and commitments in congruence with my theoretical convictions or imaginary constructs?

The question of an authentic and undivided life - personally and together - is aligned to a discovery of what Palmer (2004) calls the 'hidden wholeness'. It is at the point of discovering, or recovering, the hidden wholeness, the depth of inner vocation - which makes us into who we are authentically meant to be - that we can start to respond to the question about whose life we are living. In addition, at this point, we can start to dare imagine an alternative reality, reflective of the wholeness we are seeing and retrieving. It is an interwoven journey, in which we not only know as we are known; but we also become whole, as we share wholeness.

\section{Planning for action: 'The courage to act'}

Once we started to discern an alternative imagination in community, tracing the outlines of wholeness hidden in the fault lines of the city, and owning our own lives, not of others' making, we would naturally come to a place of needing to act.

The courage to act is what is required to immobilise our fear. Palmer's (1998:150) fearful ways of knowledge, in our contexts of engagement, made people withdraw from the city instead of immersing themselves. Yet, as Biblical people, there is the constant evocation not to be afraid (Palmer 1998:56). This invitation to act courageously is also true of other spiritual traditions.

We live in polarised, walled cities. South African cities are no longer polarised only along racial lines but are also increasingly inhabited by economically segregated neighbourhoods. Palmer (1998:61) speaks about this as 'a culture of disconnection ... driven partly by fear', but also by the Western urge and tendency to polarise.

The courage to act our alternative imaginations into being is preceded by the courage to be. The 'courage to be is the courage to accept oneself as accepted in spite of being unacceptable' (Tillich 1952:164). Tillich (1952) speaks about the 'courage to be' as an affirmation of one's own being, one's own dignity, one's own vocation and one's ability. The courage to be includes giving oneself the right to make change, but also to create spaces, such as described in discussing communities of congruence, in which we together can invite, receive and embrace our collective courage to be.

The TLF community creates space for diversity of being, where the embrace of the other gives mutual courage to be. 
People of all walks of life are welcomed equally, and the voice of every person valued and accepted. We have often witnessed the entrance into the community of someone who finds themselves utterly 'unacceptable', and the transformation of that very person into a person with the 'courage to be'.

This embrace of self, community and vocation provides the roots and confidence to live from the deep sources within. Now, once a person or community is able to embrace their own ability and right (and responsibility) to act in ways that are free from the preoccupations, requirements or dominant constructs of society, we can have the courage to act freely.

Bornstein (2004:282), in reflecting on social innovators and change-makers he met in his own research, concluded: '... the people who solve problems must somehow first arrive at the belief that they can solve problems'. It starts with the courage to be, and to act in small change-making ways, but, inevitably, 'small-scale efforts lead gradually to larger ones', as people grow in their capacity, confidence and courage to make bold change.

\section{Lived faith: 'Identity and integrity'}

Gustavo Gutierrez (1988:xxxiv) speaks about the first step of doing theology as having a lived faith. Only the second step is theological reflection. Similarly, in our understanding of change-making, courageous acts are preceded by a 'lived faith'. This might not be a courageous or bold faith, but a faith that nevertheless hangs on, amidst the paradox of urban reality; a faith that is tenacious amidst suffering, whilst stubbornly remaining imaginative in the possibilities after death. Our understanding of change-making cannot be understood outside of a 'lived faith'.

In this regard, we would like to retrieve Palmer's reflections on identity and integrity. As faith-based change-makers, our identity is namely shaped by our faith, but at the same time, the content or meaning we assign to our faith is also being shaped by our evolving identity. At the same time, it is a faith that seeks to express itself in an increased sense of integrity and wholeness (cf. Palmer 1998:9-34; 61-88), yearning, in the words of Palmer (1998:163-184), for the undivided life (and perhaps one can even consider an 'undivided faith'). All three categories - faith, identity and integrity - have to do with our inward lives.

Palmer (1998:10) suggests that 'good teaching cannot be reduced to technique; good teaching comes from the identity and integrity of the teacher'. We would like to equate it to the practice of change-making. Change-making 'comes from the identity and integrity of the teacher' and is shaped by the 'lived faith' of those practising change-making.

By identity and integrity, Palmer (1998:13) refers not only to 'our noble features, or the good deeds we do, or the brave faces we wear ...', which, he says, anyway often only gets used 'to conceal our confusions and complexities'. Instead, he says, identity and integrity also speak of 'our shadows and limits, our wounds and fears' (Palmer 1998:13), as much as it has to do 'with our strengths and potentials'.

Identity and integrity hang together. A lack of integrity results in a fragile identity. Moreover, fragile identity causes lack of integrity. It requires deep discernment, both discovering, clarifying and embracing '... what is integral to my selfhood, what fits and what does not' (Palmer 1998:13).

Identity is about making sense of who we are - both as individuals and in community - even if we only know in part at any given time. A sense of identity means to embrace the shifting nature of our own identities, as we increasingly discover who we are in relation to each other and the city and world around us. The embraced identity we consider in this reflection is one that is also embracing our shadow selves and our vulnerabilities, allowing even our own wounds to work in transformative ways.

Similarly, ' $[B]$ y choosing integrity, I become more whole, but wholeness does not mean perfection. It means becoming real by becoming the whole of who I am' (Palmer 1998:13). Integrity, therefore, in Palmer's (1998:13) understanding, is 'whatever wholeness I am able to find within that nexus as its vectors, form and re-form the pattern of my life' (Palmer 1998:13).

Integrity has to do with an integrated life. The opposite thereof, says Palmer, is a divided life. This life 'will always distance itself from others, and may even try to destroy them, to defend its fragile identity' (Palmer 1998:15-16). In speaking about educators, and we think the same applies to changemakers generally, Palmer (1998:19) says '[we] lose heart ... because teaching is a daily exercise in vulnerability', and we, mostly, opt for self-protecting, guarding our wounded selves, broken identities and questionable integrity.

In the case of faith-based change-makers, we draw from O'Connor's insistence of the importance of the inward work, if for nothing else, to serve as a reminder 'that the source of action and the source of contemplation is the same - Jesus Christ' (O'Connor 1976:117).

\section{Communities of congruence: Dangerous visions of change}

Our understanding of change-making is communal. It requires what Parker Palmer (1998:172-183) speaks of as communities of congruence. Elsewhere Palmer (2004:71-89) speaks of such communities as 'circles of trust', critically important for preparing for the journey. The spirituality we describe here is what we sought to discern, learn and practice in community together.

Such communities, in which we are allowed to be our vulnerable (and strong) selves, and in which we learn how to know in community, have the possibility to hold people 
together in ways that can allow the birthing of courageous visions of change.

Our world desperately needs communities of congruence. Our churches, faith communities, political structures, universities, civic leaders and banks, all fail us in this regard, promising what they cannot deliver upon, because of the sheer incongruence.

Communities of congruence, on the other hand, are spaces in which our walk and talk are the same; in which confessions and mission statements are embodied in actions and practices. These are communities learning to live the undivided life, instead of pretending to be what they are not. These are not pseudo-communities that pretend oneness of vision by demanding compliance, but vulnerable communities in which the real self can be faced and held, until authentic vocation is called forth, in relation to others.

Palmer (1998:172), in reference to Rosa Parks and the black church in the United States during the time of the civil rights movement, speaks of different steps or stages in the fostering of such communities. They do not simply exist without being carefully nurtured into existence.

For individuals, the first step is to reveal one's inner truth, to oneself - to discard playing a role in order to grow into one's authentic self. The expectations of family, church, peers and dominant culture often shape who we are, and instead of living into our vocation, we live what others expect of us. Once we are able and willing to face our deepest selves in the mirror, and adamant on discarding inauthentic roles, the second step is possible.

For Palmer (1998:172), the second step is for people who are on similar journeys towards the undivided life, to come together in communities that welcome such journeys very intentionally. Palmer says black churches in the time of Rosa Parks became communities of congruence that offered the movement for change a number of vital things:

1. These communities provided physical space to meet.

2. They provided 'conceptual space where the substance of the movement could be developed and sustained' (Palmer 1998:172).

3. They provided imaginative spaces in which people could 'develop the language that can represent the movement's vision, giving that language the strength it will need to survive and thrive in the rough-and-tumble of the public realm' (Palmer 1998:172).

4. They provided 'a training ground where people living undivided lives could develop the skills and habits necessary to take their values into the larger world' (Palmer 1998:173).

These are not innocent communities though. They hold and nurture dreams that are disharmonious with dominant society. They dare to think to the beat of a different drum, and unapologetically so. Palmer (1998) writes:
When discourse begins among people who have recently freed their souls, the language feels fragile - the fragility that comes when we talk about dreams in a society obsessed with practicality or about community in a society obsessed with competition or about risk taking in a society obsessed with playing it safe, people who use such language, the language of the heart, need a place to practice it, to grow accustomed to it, to have it affirmed by like-minded people before they speak it to a larger audience that may range from sceptical to hostile. (pp. 172-173)

Change-making is risky business. On the one hand, for change-makers, acting on the change to be made can be met with scepticism or hostility, as Palmer says, or downright rejection. However, it is also risky for those who are seeing themselves as custodians of a convenient status quo that works for some but harms the majority. The risk of change that might require personal sacrifice, or letting go of too many comforts, is considerable. Because of these reasons, communities of congruence are critical to hold visions for change until they are achieved.

Palmer (1998:175) says: 'Change starts in the inner self and in relationship to other like-minded people forming communities of congruence'. This is only the first stage of building a movement of change. The second stage is 'going public' (1998:175). Palmer says: 'The danger when a community remains inside is that they become introvert and the vision they have can never make change in broader society'. Going public invites critique and correctives, but also provides encouragement and accountability (Palmer 1998:175-176).

Such communities of congruence hold the potential to become liberating communities. Elizabeth O'Connor (1976:100-117), with reference to the work of the Church of the Savior in Washington, DC, speaks of the 'marks of the liberating community'. I would like to suggest these as the marks; in addition, of a community of congruence, a changemaking community, a community embracing its vocation to work for liberation-transformation, giving expression to a sense of God's shalom in the world. O'Connor (1976:100-117) mentions five such marks:

- Liberating communities have 'a clear, radical, unequivocal commitment to the poorest, the weakest, and the most abused members of the human family' (O'Connor 1976:100-102).

- Liberating communities demonstrate a 'commitment to a life of dialogue' (O’Connor 1976:102-104).

- Liberating communities practice 'a radical commitment to a critical contemplation of one's own life and the life of one's faith community' (O'Connor 1976:104-106).

- Liberating communities practice a 'commitment to a life of reflection' (O'Connor 1976:106-109).

- Liberating communities 'structure into every day a time of solitude' (O'Connor 1976:109-117).

It is telling that $\mathrm{O}^{\prime}$ Connor (1976:109) notes a daily time of solitude as 'the foremost responsibility of the Christian revolutionary'. She goes on to say: 'Without a protected time 
of daily silence we have no possibility of doing the extraordinary inward work that each of us needs to do'.

\section{Change-making in the direction of wholeness}

We understand the whole process of the praxis-cycle as aimed at transformational change, seeking to be immersed in urban fractures in ways that can mediate wholeness. Such wholeness will be marked by integrity, the undivided life and inclusive cities. Yet, this is not about building the perfect city.

Palmer (2004:5) encourages us by saying: 'Wholeness does not mean perfection: it means embracing brokenness as an integral part of life'. Being immersed in urban fractures is no guarantee that the fractures would easily, or ever, be suspended. However, it does require an embrace of the fractures as a part of our life and ministry journeys, which cannot simply be dissolved through our presence. Embracing brokenness and embracing contradiction go hand in hand. The challenge, for Palmer (2004:39-45), is on how to live 'the undivided life' amidst so many signs of fracture.

We speak of change-making in the direction of wholeness, implying ongoing journeys, but what is important for Palmer on these journeys is an assertion that we will be 'divided no more' (Palmer 2004:163-183). He means this both in terms of our inner lives but also our outer commitments and relationships. To live the undivided life, carrying everincreasing marks of wholeness, amidst imperfection, includes the notions of identity, integrity, connectedness, congruence and interdependence, inviting and allowing hidden wholeness to be revealed among us, amidst and beyond the fractures.

In communities of congruence, we might find the grace to witness healing and wholeness - for ourselves, our neighbourhoods, our institutions and our cities - drawing from wells of eternal abundance (cf. Palmer 1993:93-110).

\section{Acknowledgements}

This article was informed by the journey of the TLF, an ecumenical community organisation in Pretoria's inner city, celebrating its 25th anniversary in 2018.

\section{Competing interests}

The authors declare that they have no competing interests with regard to the writing of this article.

\section{Authors' contributions}

S.F.d.B. conceptualised the article and wrote the first draft. W.d.B. then fleshed it out more in terms of the actual journey of the TLF community and brought experiences and literature in conversation with each other. The process was an ongoing dialogical one between the two authors. S.F.d.B. finalised the content after reviewers' comments and W.d.B. attended to language and editorial matters.

\section{References}

Abyssinian Development Corporation, n.d., viewed 15 February 2018, from www. adcorp.org

Ashoka Innovators for the Public, n.d., We now live in a changemaker world, viewed 28 February 2018, from https://www.ashoka.org/en

Bakke, R., 1987, The urban Christian. Effective ministry in today's urban world, IVP, Downer's Grove, IL.

Bakke, R., 1997, A theology as big as the city, InterVarsity Press, Downer;s Grove, IL.

Beltran, B.P., 2012, Faith and struggle on Smokey Mountain: Hope for a planet in Peril, Orbis Books, Maryknoll, NY.

Blamey, A.M. \& Mackenzie, M., 2007, 'Theories of change and realistic evaluation. Peas in a Pod or Apples and Oranges?', Evaluation 13(4), 439-455. https://doi. org/10.1177/1356389007082129

Boesak, A.A., 1977, Farewell to innocence: A socio-ethical study on black theology and black power, Orbis Books, Maryknoll, NY.

Boesak, A.A., 2017, Pharaos on both sides of the blood-red waters. Prophetic critique of empire: Resistance, justice, and the power of the hopeful sizwe - A Transatlantic conversation, Cascades, an imprint of Wipf \& Stock Publishers, Eugene, OR.

Boff, L., 1986, Wat is Theologie van de Bevrijding?, Altiora-Averbode, Apeldoorn.

Bornstein, D., 2004, How to change the world: Social entrepreneurs and the power of new ideas, Oxford University Press, Oxford.

Center for Transforming Mission Kenya, 2017, viewed 15 February 2018, from www. ctmkenya.net

Cochrane, J., De Gruchy, J. \& Petersen, R., 1991, In word and in deed: Towards a practical theology of social transformation: A framework for reflection and training, Cluster Publications, Pietermaritzburg.

Conn, H.M., 1982, Evangelism, doing justice and preaching grace, Zondervan, Grand Rapids, MI.

De Beer, S., 2014, 'Whose knowledges shape our city? Advancing a community-based urban praxis', De Jure 47(2), 218-230.

Connell, J.P. \& Kubisch, A.C., 1998, 'Applying a theory of change approach to the evaluation of comprehensive community initiatives: Progress, prospects, and problems', The Aspen Institute, Washington, DC.

De Beer, S.F., 2014, 'Whose knowledges shape our city? Advancing a communitybased urban praxis', De Jure 47(2), 218-230.

De Beer, S.F., 2017, Mother bird, hovering over the city: Space, spirituality and a community-based urban praxis, Unpublished PhD-thesis in Town and Regional Planning, University of Pretoria.

De Beer, S.F. \& Vally, R., 2015, Pathways out of homelessness, Research Report 2015, University of Pretoria, Pretoria.

De Beer, S. \& Venter, D., 1998, Doing theology in the city, Workbook One, Institute for Urban Ministry, Pretoria.

Faith \& Leadership, 2009, Mary Nelson: Embracing God's vision for community, Faith and Leadership, viewed 15 February 2018, from https://www.faithandleadership. com/mary-nelson-embracing-gods-vision-community

Freedman, J. \& Combs, G., 2001, Narrative therapy. The social construction of preferred realities, W.W. Norton \& Company, New York.

Freire, P., 1970, Pedagogy of the oppressed, Herder and Herder, New York.

Freire, P., 1992, Pedagogy of hope, The Continuum Publishing Company, London.

Fulbright-Anderson, K. \& Auspos, P., 2006, Community change: Theories, practice, and evidence, The Aspen Institute, Washington, DC.

Greenway, R.S. (ed.), 1979, Discipling the city. Theological reflections on urban mission, Baker Book House, Grand Rapids, MI.

Gutierrez, G., 1988, A theology of liberation, Orbis Books, Maryknoll, NY.

Holland, J. \& Henriot, P., 1992 (1983), Social analysis. Linking faith and justice, Orbis Books, Maryknoll, NY.

Kritzinger, J.N.J., 1991, 'Re-evangelising the white church', Journal of Theology for Southern Africa 76(September), 106-116.

Linthicum, R.C., 1991a, City of God City of Satan. A biblical theology of the urban church, Zondervan Publishing House, Grand Rapids, MI.

Linthicum, R.C., 1991b, Empowering the poor. Community organizing among the city's 'Rag, Tag and Bobtail', Marc, Monrovia, CA.

Mahlokwane, J., 2018, 'City joins global drive to get people off the streets', Pretoria News, 19 March, p. 3.

Matsena, D., 2018, 'Hope for the homeless of Pretoria', Rekord Pretoria East, 23 March, p. 3.

Mofokeng, T., 1983, The crucified among the cross-bearers: Towards a black Christology, Uitgeversmaatskappij J.H. Kok, Kampen.

Murthy, N.R., 2004, 'Foreword', in D. Bornstein (ed.), How to change the world: Social entrepreneurs and the power of new ideas, pp. xii-xiii, Oxford University Press, Oxford.

Nolan, A., 1991, Jesus before Christianity, Orbis Books, Maryknoll, NY.

Nouwen, H.M.J., 1972, The wounded healer: Ministry in contemporary society, Doubleday, Garden City, NY.

Nouwen, H.M.J., 1979, Clowning in Rome: Reflections on solitude, celibacy, prayer, and contemplation, Image Books, Garden City, NY.

O'Connor, E., 1976, The new community, A portrait of life together in words and pictures, Harper \& Row Publishers, New York. 
Palmer, P.J., 1983a, To know as we are known: Education as a spiritual journey, HarperOne, San Francisco, CA.

Palmer, P.J., 1983b, The company of strangers: Christians and the renewal of America's public life, Crossroad, New York.

Palmer, P.J., 1993, The promise of paradox: A celebration of contradictions in the Christian life, Jossey-Bass, San Francisco, CA.

Palmer, P.J., 1998, The courage to teach: Exploring the inner landscape of a teacher's life, Jossey-Bass, San Francisco, CA.

Palmer, P.J., 2000, Let your life speak: Listening for the voice of vocation, Jossey-Bass, San Francisco, CA.

Palmer, P.J., 2004, A hidden wholeness: The journey toward an undivided life, JosseyBass, San Francisco, CA

PCUSA, n.d., Confession of Belhar, September 1986, viewed 15 February 2018, from https://www.pcusa.org/site_media/media/uploads/theologyandworship/pdfs/ belhar.pdf
Rowles, M. \& Schell, B., 2001, A human in action: The reverend Hans Visser of the Pauluskerk in Rotterdam, humanity in action, viewed 15 February 2018, from https://www.humanityinaction.org/knowledgebase/12-a-human-in-action-thereverend-hans-visser-of-the-pauluskerk-in-rotterdam

Russell, L., 1987, Household of freedom: Authority in feminist theology, Westminster/ John Knox Press, Louisville, KY.

Shaper, D., 1989, A book of common power: Narratives against the current, LuraMedia, San Diego, CA

Shorter, A., 1991, The church in the African city, Orbis Books, Maryknoll, NY

Soelle, D., 1993, Celebrating resistance: The way of the cross in Latin America, Mowbray, Woonsocket.

Soelle, D., 2001, The silent cry: Mysticism and resistance, Orbis Books, Maryknoll, NY. Tillich, P., 1952, The Courage to Be, 2nd edn., 2000, Yale University Press, New Haven, CT. Vanier, J., 1979, Community and growth, Paulist Press, New York. 